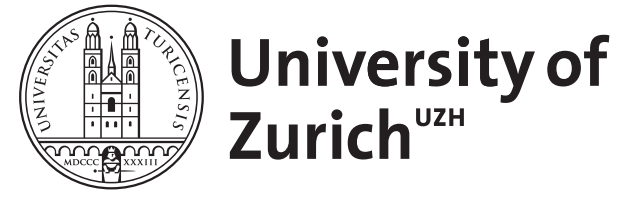

New Perspectives of the Early Modern Afterlife: The Last Pilgrimage in the Poetry of John Donne and Sir Walter Raleigh

\author{
Caspar, Cyril L
}

DOI: https://doi.org/10.1515/9783110436976-017

Posted at the Zurich Open Repository and Archive, University of Zurich

ZORA URL: https://doi.org/10.5167/uzh-124821

Book Section

Published Version

Originally published at:

Caspar, Cyril L (2016). New Perspectives of the Early Modern Afterlife: The Last Pilgrimage in the Poetry of John Donne and Sir Walter Raleigh. In: Classen, Albrecht. Death and the Culture of Death in the Middle Ages and Early Modern Time: the Material and Spiritual Conditions of the Medieval and Early Modern Culture of Death. Berlin: Walter de Gruyter, 432-456.

DOI: https://doi.org/10.1515/9783110436976-017 


\section{Cyril L. Caspar (University of Zurich, Switzerland) New Perspectives of the Early Modern Afterlife: The Last Pilgrimage in the Poetry of John Donne and Sir Walter Raleigh}

The last pilgrimage as a way of depicting the passage from this life into the next is a recurring trope among writers in early modern England. ${ }^{1}$ Best known in this regard is probably John Bunyan's The Pilgrim's Progress (1679/1684) featuring the Everyman figure Christian, his spiritual adventures on the pilgrimage to the Celestial City, and his successfully crossing the River of Death together with his companion Hopeful. ${ }^{2}$ Bunyan's bestseller, and particularly the journey on which the two pilgrims cast off "their Mortal Garments," is indebted to many different earlier precedents in the literary works of the English Renaissance. ${ }^{3}$ In this paper, I will focus on two of these and argue for their strong met-

1 I am indebted to Albrecht Classen, Christina Ljungberg, Allen Reddick, Fabian Schambron, Thomas Willard, and Florence A. Zufferey as well as to the participants of the symposium Death and the Culture of Death in the Middle Ages and Early Modern Time (May 2015, The University of Arizona, Tucson) for their valuable criticism that helped to improve this article at various stages. Original spellings have been retained; old letter forms and abbreviations have been silently adapted and expanded, respectively. Unless otherwise noted, early printed books have been accessed through Early English Books Online. The research for this paper was supported by grant no. FK-14-059 from the "Forschungskredit" of the University of Zurich.

2 John Bunyan, The Pilgrim's Progress, 1678/1684, ed. Cynthia Wall (New York and London: W. W. Norton, 2009), 121-22. For a literary study that focuses on the this-worldly aspect of the pilgrimage in early modern England rather than on the metaphorical implications of its end, see Grace Tiffany, Love's Pilgrimage: The Holy Journey in English Renaissance Literature (Newark, DE: University of Delaware Press, 2006).

3 Among others, I am thinking of works like Edmund Spenser's The Faerie Queene (1590/1596) and shorter poems by George Herbert, John Donne, and Sir Walter Raleigh. On another note, Watson argues that the question of "the proper path to the afterlife" was only a means of psychological distraction from the possibility that there might be "no destination" at all. This view is based on Watson's overall argument that the English Renaissance witnessed an unprecedented crisis of death mainly due to "the lack of any purgatorial process" and due to Protestantism's "particular emphasis on individual interiority" and on its inherent sinfulness that "must have made it virtually impossible to imagine satisfactorily the survival of a full selfhood in heaven." Even though historians think that this is exaggerated, many concur on the "eschatological uncertainties" that some of the old/new Protestant doctrines unleashed. Thus, even if death's "nihilistic sting," as Watson calls it, is an exaggeration, I would argue that the metaphorical pilgrimage projects a conceit that professes to transcend linguistically these ontological anxieties to explore new, hopeful meanings of the life to come. See Robert N. Watson, The 
aphorical potential of opening up new perspectives of the early modern afterlife. To do so, I will first consider one of John Donne's Holy Sonnets that offers a condensed but deep insight into the ruminations of a person at the point of death. On the "last mile" of the speaker's earthly pilgrimage his sins are cast to hell, entitling his soul to leave behind the world, the flesh, and the devil, so that he may rejoin-in a typically Donnean twist-a fully purified body in heaven. For a contrast to Donne's sonnet, I will turn to "The Passionate mans Pilgrimage," a poem usually attributed to Sir Walter Raleigh, in which the speaker-convict envisions his own execution, his ensuing pilgrimage to a heavenly court of justice, and his assurance of Christ's atonement. All of this gives him the opportunity to criticize fiercely the worldly authorities whom he holds responsible for his earthly fate.

I will contend that, even though these two poems are very different in tone, scope, and end, the common metaphor of the last pilgrimage reveals new meanings of after-worldly being. Via the last pilgrimage, Donne's poem invites the reader into a dying person's most inner thoughts, subtly alluding to the postmortem reunion of his body and soul. The poem attributed to Raleigh, on the other hand, uses the trope for a political cause, namely, to denounce those earthly authorities responsible for the speaker's death sentence by opening up a new perspective on heavenly justice.

Prior to the analysis of the two poems, a few historical and theoretical aspects need to be addressed. ${ }^{4}$ Historically, the idea of the pilgrimage as a metaphorical journey through life is not an invention of the English Renaissance. The trope can be traced as far back as to the Old Testament narratives of a chosen people on their quest for the land of milk and honey. This quest is appropriated in the New Testament, particularly in Hebrews 11, where humans in this

Rest Is Silence: Death as Annihilation in the English Renaissance (Berkeley, Los Angeles, et al.: University of California Press, 1994), 6, 40; Peter Marshall, Beliefs and the Dead in Reformation England (Oxford and New York: Oxford University Press, 2002), especially 215; Ralph A. Houlbrooke, Death, Religion, and the Family in England, 1480-1750 (Oxford, New York, et al.: Clarendon Press, 1998); David Cressy, Birth, Marriage, and Death: Ritual, Religion, and the Life-Cycle in Tudor and Stuart England (Oxford and New York: Oxford University Press, 1997).

4 While medievalists have amply covered the pilgrimage trope, much of the same work remains to be done for the early modern period, particularly in regard to the eschatological implications of this metaphor. A list of seminal studies on the topic includes but is not limited to Jonathan Sumption, Pilgrimage: An Image of Mediaeval Religion (Totowa, NJ: Rowman and Littlefield, 1976); Victor Turner, Image and Pilgrimage in Christian Culture: Anthropological Perspectives (Oxford: Basil Blackwell, 1978); Dee Dyas, Pilgrimage in Medieval English Literature, 700-1500 (Cambridge: D. S. Brewer, 2001); Marco Nievergelt, Allegorical Quests from Deguileville to Spenser (Cambridge: D. S. Brewer, 2012). 
world are described as strangers and pilgrims in a foreign country headed for the eternal city which God has prepared for them. ${ }^{5}$ Throughout the period of the early Christian Church and the Middle Ages, the concept of the "life pilgrimage" with its ultimately eschatological goal (perhaps best known in Dante's Divina Commedia) was retained despite the rising popularity of the "place pilgrimage"-a medieval practice that today seems much more prevalent in our heads than its metaphorical precedent. ${ }^{6}$

In the wake of the (English) Reformation, the abolition of the place pilgrimage for reasons of charges against idolatry may well have led to a re-emphasis of the arduous pilgrimage through life as a conceit for the this-worldly toils and their after-worldly obliteration. Hence, the metaphorical pilgrimage provided believers not only with an experiential model of mapping their spiritual progress but also with a way of putting life and death into perspective: upon the close of his earthly life, the stranger-pilgrim is bound to take his last journey to his heavenly home. ${ }^{7}$ In this connection, the pilgrimage trope was also used by early modern divines pastorally to palliate the prospects of death, a fact to which a number of church historians refer cursorily and to which sermons and other devotional writings by Erasmus of Rotterdam, John Calvin, Thomas Becon, and others bear explicit testimony. ${ }^{8}$ All these aspects-the biblical ori-

5 See Hebrews 11:13-16. The rendering of "strangers and pilgrims" may seem inaccurate in

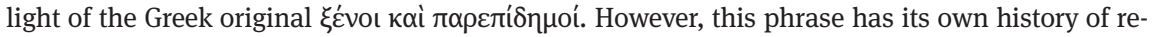
ception in English bible translations: it goes back to the Wycliffite Bible, translated on the basis of Jerome's Vulgate ("peregrini et hospites") rather than the Greek original. A similar passage can also be found two chapters later in Hebrews 13:14. For the history of reception, see Philip Edwards, Pilgrimage and Literary Tradition (Cambridge, New York, et al.: Cambridge University Press, 2005), 5-6.

6 Dee Dyas, Pilgrimage in Medieval English Literature, 700-1500 (see note 4), 9-65. To differentiate between the metaphorical pilgrimage through life and the literal pilgrimage to a particular shrine, Dyas has coined the terms "life pilgrimage" and "place pilgrimage," respectively. Moreover, it deserves emphasis that the idea of an interior pilgrimage had never disappeared entirely and was retained particularly in medieval mysticism, while the idea of a literal pilgrimage was never without criticism; see Victor Turner, Image and Pilgrimage in Christian Culture (see note 4), 7; Giles Constable, "Opposition to Pilgrimage in the Middle Ages," Studia Gratiana 19 (1976): $121-46$.

7 On the experiential mode of the Protestant narrative, see Neil H. Keeble's work on itinerancy, particularly his essay, “'To be a pilgrim': Constructing the Protestant Life in Early Modern England," Pilgrimage: The English Experience from Becket to Bunyan, ed. Colin Morris and Peter Roberts (Cambridge, New York, et al.: Cambridge University Press, 2002), 238-56.

8 Ralph A. Houlbrooke, Death, Religion, and the Family (see note 3), 65; Marshall, Beliefs and the Dead (see note 3), 309. 
gins, the medieval practice of place pilgrimage, the Protestant model for spiritual progress, and the palliative implications of early modern pastoral care-need to be kept in mind when further approaching the core of the matter.

\section{The Pilgrimage Metaphor in Theory}

My research is based on the theoretical premise that the end of the metaphorical pilgrimage functions as a conceit to negotiate the tension between soteriology and eschatology, two dogmatic disciplines theorized in systematic theology. In the most simple terms, soteriology adumbrates the earthly ways in which God grants salvation to humanity, while the doctrine of eschatology is ultimately concerned with the "last things," that is, the after-worldly consequences of God's salutary acts (heaven, hell, resurrection, last judgment) in both individual and collective terms. ${ }^{9}$ In spite of the New Testament's insistence on the Good News and the eventual salvation of mankind, the tension between the redemption through the figure of Jesus Christ and its effectual fulfillment remains unresolved until the end of times. This is a dogmatic tension that has not ceased to exist for Christians of any epoch. For the present inquiry, it can be said that the pilgrimage trope conceptualizes this tension metaphorically: the life pilgrimage is a soteriological model that sketches the metaphorical steps in this life, and its end inevitably anticipates an eschatological conclusion. Hence, the last pilgrimage is the immediate bridge between soteriology and eschatology, between this life and the one to come.

While I do not intend to make a completely new contribution to what Paul Ricœur calls the "boundless field of metaphor theory," my literary analysis relies on some of the most central insights that have been put forward by theorists of metaphor. ${ }^{10}$ In his reading of Aristotle's Poetics, David Punter paraphrases that through the special capacity of a metaphor the reader is cast into "the presence of something unusual, something outside language's normal ambit, and this can serve to deepen the reader's experience, to bring a suddenly enriched apprehension of the world." 11 How this metaphorical enrichment is exploited can be further explained by turning to Ricœur: by borrowing the Fregean distinction be-

9 Rochus Leonhardt, Grundinformation Dogmatik, 3rd ed. (2001; Göttingen: Vandenhoeck \& Ruprecht, 2008), 310, 388; see p. 390 for the difference between individual and collective eschatology.

10 Paul Ricœur, “The Metaphorical Process as Cognition, Imagination, and Feeling," Critical Inquiry 5.1 (1978): 143-59; here 143.

11 David Punter, Metaphor. The New Critical Idiom (London: Routledge, 2007), 13. 
tween the sense (German Sinn), "the immanent design of discourse," and its reference (German Bedeutung), "the intentional direction towards a world," Ricœur presents a tension theory according to which "a previously unnoticed 'proximity' of two ideas is perceived despite their logical distance."12

This new correlation between the sense of a metaphorical statement and its reference gives rise to a "semantic innovation," as Ricœur calls it, a term that becomes helpful when theorizing death through the end of the earthly pilgrimage: while, to believers in early modern England, the literal sense of the end of a pilgrimage may just have referred to the medieval place-pilgrim reaching his shrine, the metaphorical reference, I argue, achieves an unprecedented semantic proximity between life and death, leading to "a new vision of reality to which ordinary language [...] stands in opposition." 13 Put differently, the meaning of that which cannot be expressed literally, that is death itself, is suspended through the use of figurative language, a kind of language capable not only of putting life and death into a metaphorical relationship and of thereby providing "tropological consolation," but also of entering literary works through poetic innovation and exploration. ${ }^{14}$

Although the two dogmatic disciplines of soteriology and eschatology are theoretically not congruent with the literal sense and the metaphorical reference, I contend that there is a certain parallel, for both soteriology and Ricœur's literal sense share an aspect of immanence, while eschatology and his metaphorical reference both transcend this-worldly life and language. This linguistic relationship of religious metaphors has been further enunciated by Hans Weder, a New Testament theologian whose research is closely associated with Ricœur's. Weder maintains that a religious metaphor has a "hermeneutical potential" insofar as it "can be defined as combining a transcendent subject with an immanent predi-

12 Paul Ricœur, "Metaphor and the Main Problem of Hermeneutics," New Literary History 6.1 (1974): 95 -110; here 100; Paul Ricœur, The Rule of Metaphor: The Creation of Meaning in Language, 1975, 1977, trans. Robert Czerny with Kathleen McLaughlin and John Costello (London: Routledge, 2004), 4. Also, see Paul Ricœur, "Stellung und Funktion der Metapher in der biblischen Sprache," Metapher: Zur Hermeneutik religiöser Sprache, ed. Paul Ricœur and Eberhard Jüngel (Munich: Chr. Kaiser, 1974), 48. In other theories of metaphor, these "two ideas" are often referred to as subject and predicate or tenor and vehicle, respectively.

13 Ricœur, "Stellung und Funktion der Metapher," (see note 12), 51 (my translation).

14 That metaphorical language is able "to provide tropological consolation" has been established in at least one literary study, see Karen Elizabeth Smythe, Figuring Grief: Gallant, Munro, and the Poetics of Elegy (Montreal: McGill-Queen's University Press, 1992), 13. The close relationship between figurative and poetic language is already delineated in Aristotle's Poetics and a commonly accepted premise in Ricœur's thought, which is why I desist from explaining it in further detail here. 
cate," while balancing an insurmountable difference between the worldly and the divine, or between this life and the next, for that matter. ${ }^{15}$ It is precisely within this arena of the here and now and the hereafter that the trope of the last pilgrimage can open up new perspectives for the life to come through the literary use of metaphor as I will demonstrate below.

\section{The Pilgrimage Metaphor in Early Modern Theology}

While it was not possible for early modern believers to draw from Ricœur or Weder for insights on a life-transcending metaphor, they had other opportunities to grapple with such theological issues in various devotional manuals which were widely available. In this regard, the literary tradition of the medieval ars moriendi is of particular interest as it survived the Protestant onslaught and saw many variegated revivals far into the late seventeenth century. ${ }^{16}$ In Craft and Knowledge For to Dye Well (ca. 1490), which may be considered the first English contribution to the genre in English, the anonymous author speaks at various points of "the exyle of thys worlde" (1). ${ }^{17}$ This is a phrase that obviously harks back to the Old Testament and to the seemingly endless wanderings of God's people in a foreign land, upon which later ars writers will expand. One of them is Erasmus, who in Preparation to Deathe (1538) declares:

15 Hans Weder, "Metaphor and Reality," The End of the World and the Ends of God: Science and Theology on Eschatology, ed. John Polkinghorne and Michael Welker. Theology for the TwentyFirst Century, 21 (Harrisburg, PA: Trinity Press International, 2000), 291-97; here 292; Hans Weder, "Metapher und Gleichnis: Bemerkungen zur Reichweite des Bildes in religiöser Sprache," Zeitschrift für Theologie und Kirche (ZThK) 90 (1993): 382-408; here 403.

16 Some excellent work has been done on the late medieval and early modern literary genre of the ars moriendi. I am particularly indebted to Nancy Lee Beaty, The Craft of Dying: A Study in the Literary Tradition of the Ars Moriendi in England (New Haven, CT, and London: Yale University Press, 1970); David W. Atkinson, “The English ars morendi [sic]: Its Protestant Transformation,” Renaissance and Reformation/Renaissance et Réforme 6.1 (1982): 1-10; David Cressy, Birth, Marriage, and Death (see note 3), 389-93; Houlbrooke, Death, Religion, and the Family (see note 3), 149-52, 157-75; for the most recent contribution to the field, see Amy Appleford, Learning to Die in London, 1380-1540. Philadelphia, PA: University of Pennsylvania Press, 2015.

17 Parts of the English ars literature are anthologized in David W. Atkinson, ed., The English Ars Moriendi. Renaissance and Baroque Studies and Texts, 5 (New York, San Francisco, et al.: Peter Lang, 1992). Unless otherwise noted, I am quoting from this volume with indicated page references parenthetically. 
We be wayfarynge men in this worlde, not inhabytantes. We be as straungers in innes, or to speke it better, in bouthes or tentes. We lyue not in our countrey. This holle lyfe is nothynge elles but a rennynge to deathe, and that very shorte, but death is the gate of euerlastynge lyfe. (38)

The trope that life is a race to eternity is a commonplace in the New Testament (cf. 1 Cor. 9:24-27, Phil. 3:12-14, 2 Tim. 4:7-8, Heb. 12:1). But on a more abstract level, death here is portrayed as the inevitable transition from the shortness of this-worldly life to heavenly eternity. This contrast then paves the way for Erasmus to embrace the popular notion of the contemptus mundi: on the basis of 2 Corinthians 4:18, he argues that "this is a greate parte of the Christen philosophie, whiche prepareth vs to dethe, that by the contemplation of the thinges eternall and heuenly, we maye lerne the despisynge of temporall and erthly." ${ }^{18}$ We will re-encounter this fierce contempt of what is left behind in both literary texts later.

Protestant theologians were no less reluctant to express contempt for thisworldly life with regard to what lies ahead and often refer to the popular pilgrimage metaphor. In The Institution of Christian Religion (1561), John Calvin exhorts his readers to express "contempt of this present life, \& therby be stirred to the meditation of the life to come."19 Moreover, he criticizes those who call themselves Christians and still fear death, for "If we consider that by death we are called home out of banishment [Latin: 'per mortem ab exilio'], to inhabite our contry, yea a heauenly contrey, shall we obteine no comfort there by?"20 Until death calls the devout Christian home, however, it is clear to Calvin that man is on a burdensome pilgrimage of progress:

18 Unfortunately, Atkinson omits this passage in his anthology, which is why I am quoting from the English translation of Erasmus's, Preparation to Deathe: A booke as deuout as eloquent, trans. probably by Thomas Berthelet from De Preparatione ad mortem (London: Thomas Berthelet, 1538), A5v. On the trope of the contemptus mundi, see, among others, David E. Stannard, The Puritan Way of Death: A Study in Religion, Culture, and Social Change (New York: Oxford University Press, 1977), 21, 23.

19 John Calvin, The Institution of Christian Religion, wrytten in Latine by maister Ihon Caluin and translated in Englysh according to the authors last edition, trans. Thomas Norton (London: Reinolde Wolfe \& Richarde Harison, 1561), bk. 3, chap. 9, sec. 1. The many abridged compendia in both Latin and English as well as the many editions and reprints of Thomas Norton's full English translation (the one quoted here) suggest a wide readership in early modern England; see John T. McNeill, "Introduction," Calvin: Institutes of the Christian Religion, ed. John T. McNeill, 2 vols. (1960; Louisville, KY: Westminster John Knox Press, 2006), vol. 1:xlii-xlv, xlviii-l.

20 Calvin, Institution of Christian Religion (see note 19), bk. 3, chap. 9, sec. 5. 
so longe as we wander from home in thys worlde, our faith is not fully expressed, not onely bicause many things are yet hidden from vs, but bicause being compassed with many mistes of erroures, we atteine not all things. ${ }^{21}$

Significantly, the phrase "we wander from home in thys worlde" is a rendering of the original Latin text, where we read "in mundo peregrinamur," which is indicative of the original meaning of peregrinus as "a wanderer, a traveller from foreign parts, an alien."22

Around the same time of the first English translation of Calvin's Institutes, Thomas Becon's The Sicke Mans Salve was published. ${ }^{23}$ Already in the dedicatory epistle, Becon bewails man's blindness and willingness to cling to earthly matters, but by direct reference to Hebrews 11:13-16 and 13:14, he invokes the popular pilgrimage trope: "The holy scripturs calleth vs strangers and Pilgrims in this worlde, \& declareth that we haue here no continuying city, but we seke one to come."24 Further into the main text, which essentially comprises a dialogue around the deathbed, this idea is elaborated as the metaphor of the strangers and pilgrims in exile is used to underscore how wretched the conditions in this life are compared to the glories that await the elect. ${ }^{25}$ After providing the dying Epaphroditus with scriptural evidence that death is neither terrible nor

21 Calvin, Institution of Christian Religion (see note 19), bk. 3, chap. 2, sec. 4.

22 John Calvin, Institutio christianae religionis, in libros quatuor nunc primum digesta, certisque distincta capitibus, ad aptissimam methodum: aucta etiam tam magna accessione ut propemodum opus novum haberi possit (Geneva: Robert Estienne, 1559), bk. 3, chap. 2, sec. 4 [last accessed through e-rara: http://www.e-rara.ch/doi/10.3931/e-rara-2664, July 18, 2014]; Edwards, Pilgrimage and Literary Tradition (see note 3), 6. A still fairly authoritative work on Calvin's eschatology is Heinrich Quistorp, Die letzten Dinge im Zeugnis Calvins: Calvins Eschatologie (Gütersloh: C. Bertelsmann, 1941), which also offers a good summary of how Calvin uses the pilgrimage trope $(18-20)$.

23 It is assumed that it was already written during the reign of Edward VI; see Houlbrooke, Death, Religion, and the Family (see note 3), 157.

24 Again, this passage is not anthologized in Atkinson, which is why I am referring to the original publication, Thomas Becon, The Sycke Mans Salue. Wherein the faithful christians may learne both how to behave them selues paciently and thankefully, in the tyme of sickenes, and also vertuously to dispose the corporall goodes, and finally to prepare them selues gladly and godly to die (London: Iohn Day, 1561), *4r. One page later, he adds that as such "straungers and pylgrims [...] we shall leaue behynde vs, whatsoeuer worldly substance we haue here [...], that we shal die the death, that we shal appeare before the iudgement seat of Christ and receaue accordinge to the workes which we haue doone in this lyfe, either euerlasting glory or perpetuall payne" $\left({ }^{\star} 5 \mathrm{v}-{ }^{\star} 5 \mathrm{r}\right)$. In his marginalia, Becon exclusively refers to Hebrews 13 , but the phrase "strangers and pilgrims" is only explicit in Hebrews 11 .

25 Becon's Calvinist thrust has been noted by a number of readers; see Beaty, The Craft of Dying (see note 16), 108-156; Atkinson, ed. The English Ars Moriendi (see note 17), xix. 
fearful nor painful, Philemon addresses the latter's worries that "Death taketh me away from my gorgious and pleasaunte houses, and from all the temporall thinges that I haue” (114). ${ }^{26}$ Philemon's response merits a longer quote:

In thys worlde we all are but strangers \& pelgrimes. We haue here no dwelling citie, but looke for an other that is to come [...]. The houses that you leaue behinde you here, be they neuer so gorgious and pleasaunt, are but earthly, made of clay \& weatherbeaten stones, and shall in processe of time decay, and returne vnto dust, \& become thinges of naught. But after your departure from this vale of wretchednesse, you shall haue a building of God, an habitation not made with handes, but euerlasting in [...] heauen [...]. You shall dwel in a citie that is of pure gold, like vnto cleare glasse, and the foundations of the walles of this citie are garnished wyth all manner of precious stones, the gates are of fine pearle. Yea the stretes of this heauenly citie are pure golde [...]. And as touching your other temporal things, from the which as you say, death taketh you away, you haue no cause to be sory for that, for, as concerning your galant apparell, which, if they be not worne, will sone be motheaten. [...] In the stead of them, you, being once placed in the heauenly citie, shall be clothed of God with white garments, which shall neuer ware old, but alwayes abide glorious \& incorruptible .... (ibid.) ${ }^{27}$

In an intimately pastoral move, Philemon (or Becon himself) ${ }^{28}$ adduces scriptural proof as to why giving up all one's earthly possessions should be strived at rather than avoided. Apart from Hebrews 11, which we already encountered in Calvin and Erasmus above, Philemon attempts to dispel Epaphroditus's fears of relinquishing his temporal things by referring to 2 Corinthians 5:1 and the idea of the dissolved earthly tabernacle being replaced with an eternal heavenly dwelling. Moreover, Revelation 21:15 is invoked with its glorious depictions of the heavenly city, to which we will return in our discussion of Raleigh's poem below. All of these after-worldly references somehow rely on the fact that man in this world is seen as but a stranger and pilgrim and that his heavenly destiny, the goal of his pilgrimage, is to become revealed as the richly adorned home for which he has been yearning.

Although authors such as Erasmus, Calvin, and Becon may at times share little common theological ground, they all at some point resort to the pilgrimage trope in order to relate the plights of the present life to the glories of the one to come. The metaphorical reference of being in exile or being a stranger and pilgrim never surfaces in isolation, but it always conveys a strong thrust toward the life to come. In all of these instances, the metaphor of the life pilgrimage

26 For the New Testament episode of the sick Epaphroditus, see Philippians 2:25-30.

27 Atkinson's convention of using italics for expanded abbreviations has been retained in this passage.

28 Beaty, The Craft of Dying (see note 16), 113. 
that eventually leads to heavenly eternity to different degrees purports to transcend earthly matters by unfolding and developing new and meaningful perspectives of the life to come.

\section{The Pilgrimage Metaphor in John Donne's Poetry}

In “This is my playes last scene," usually considered the sixth of John Donne's Holy Sonnets, we find ourselves in a similar situation. The poem begins with the popular metaphor for life as a play that has reached its final scene, ${ }^{29}$ but already the first line also introduces the concept of the last pilgrimage:

This is my playes last scene, here heavens appoint

My pilgrimages last mile; and my race

Idly, yet quickly runne, hath this last pace,

My spans last inch, my minutes latest point. $(11.1-4)^{30}$

The striking repetition of "last" in "last scene," "last mile," "last inch," "last pace," and "latest point" (which is also "last point" in one manuscript) ${ }^{31}$ seems to move toward the end of each line the further the sonnet develops pointing to the impending end of the speaker's earthly life. Although there is a clear reference to Hebrews 12:1, "let vs runne with pacience the race that is set before vs," the patience of the speaker is soon to be exhausted, for his race is "quickly runne" (1. 3): no longer is his entire life set before him, but only the final part. ${ }^{32}$ This notion is even reinforced in line 4, where the end of his race is no longer a

29 This is of course reminiscent of William Shakespeare's As You Like It and Jacques's "All the world's a stage" speech, but it is a commonplace that is much older as is shown in Lynda Gregorian Christian, Theatrum Mundi: The History of an Idea (Cambridge, MA: Harvard University, 1969; reprint, New York: Garland, 1987).

30 I am quoting from the 1635 edition of Donne's poems, Poems, By J[ohn] D[onne] with Elegies on the Authors Death (London: M.F., 1635), 335. In all the editions after 1633, this poem is referred to as No. 6, a practice that has been retained among critics of the poem in spite of Helen Gardner's suggestion for some loose continuity in the 1633 sequence, where this poem is placed third. For this and some textual variants of the poem, see Helen Gardner, "Introduction \& Textual Introduction," John Donne: The Divine Poems, ed. Helen Gardner (Oxford, London, et al.: Clarendon Press, 1978), xv-xcvi.

31 See "This is my playes last scene," 1633, in John Donne: The Divine Poems, ed. Helen Gardner (Oxford, London, et al.: Clarendon Press, 1978), 7, 1. 4.

32 I am quoting from the Geneva Bible of 1560, a translation that would have been known by both Donne and Raleigh; see The Geneva Bible: A Facsimile of the 1560 Edition (Madison, WI: University of Wisconsin Press, 1969). 
mile away but an inch! The second half of the octave, then, revolves around the union of his body and soul and how they are separated at the point of death:

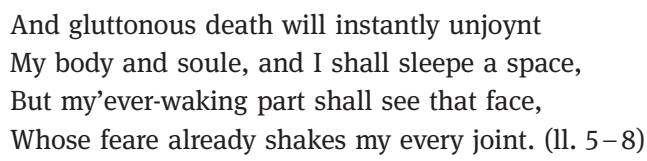

The "I" in the second half of line 6 must refer to his body that he envisions to fall into a post-mortem sleep, for the speaker's "ever-waking part," his soul, already participates in a visio Dei as most critics interpret this line. ${ }^{33}$ A profound feeling of fear permeates this second quatrain, a feeling that apparently can only be addressed by again zooming in on the separation of the speaker's body and soul in the sestet that follows:

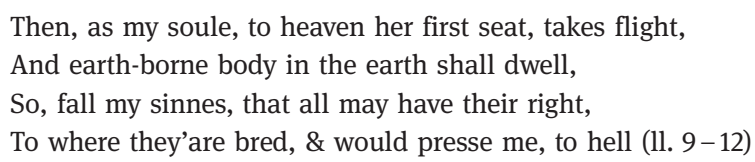

The speaker here insists that the "earth-borne body" remain in the earth and that all the speaker's sins fall from there to their place of origin, to hell. The final couplet seemingly abruptly concludes the sonnet and quite possibly the journey:

Impute me righteous, thus purg'd of evill,

For thus I leave the world, the flesh, the devill. (1l. 13-14)

Eventually, purgation of evil and divine imputation are here given as the prerequisites for him to leave behind the world and all things carnal and diabolical.

What at first sight looks like a more or less simple account of a soul's passage from this world to the next, has puzzled critics over the last few decades. Barbara Lewalski criticizes that Donne's wit in this poem is "strained"; A. L. French finds it "rather queer" that the speaker can so easily dissociate himself from his sins and that his soul departs so freely in spite of the prospect of seeing "that face"; and Richard Strier remarks that "[t]he whole point of the [Protestant] doctrine of imputation was to oppose the idea that one had to be 'purg'd of evill' to be saved," so the speaker's ruminations, Strier maintains, are actually contra-

33 See, for instance, Richard Strier, “John Donne Awry and Squint: The 'Holy Sonnets,' 16081610,” Modern Philology 86.4 (1989): 357 -84; here 373. 
dictory, not to say futile. ${ }^{34}$ In what follows, I shall argue that many of the issues that are raised in this poem can actually be explained by two aspects that-if ever-have so far been considered by critics only en passant; on the one hand, I will contend that much of this poem is about taking leave of "the world, the flesh, the devill" and about engaging in a deathbed scene that can be read in close relation to the ars moriendi. On a second note, I will argue that the speaker's ruminations at the point of death are resolved in the "I" of the final couplet, which assumes paramount importance. Read together with one of Donne's sermons, it suggests a semantic innovation of a new heavenly reunion between the speaker's body and soul, the two most central constituents of the Donnean self, as has recently been advanced..$^{35}$

As many historians have pointed out, attitudes toward death changed in the wake of the Reformation, or rather, change was imposed by the ecclesiastical authorities. ${ }^{36}$ Importantly, in terms of good and bad deaths, no clear distinctions can be drawn between an ideal pre-Reformation deathbed scene and a Protestant one; only some tendencies can be delineated. ${ }^{37}$ In late-medieval times, the final moment before the dying person exhaled their last breath was often sacramentally critical as final (non-)repentance could lead to heavenly bliss, temporary purgatory, or eternal damnation. ${ }^{38}$ According to Philip Benedict, there was a "pre-Reformation emphasis on the deathbed struggle that the dying person had to fight against despair and the devil's temptations." 39 For example, at least one ars moriendi manual from around 1450 exhibits illustrations of a deathbed (cf. Fig. 1) not only surrounded by the familial and clerical by-

34 Barbara Kiefer Lewalski, Protestant Poetics and the Seventeenth-Century Religious Lyric (Princeton, NJ: Princeton University Press, 1979), 268; A. L. French, "The Psychopathology of Donne's Holy Sonnets,” Critical Review (Melbourne) 13 (1970): 111-24; here 116; Strier, "John Donne Awry and Squint" (see note 33), 373-74.

35 Ramie Targoff argues that "Donne's writing is fueled by a set of metaphysical questions, and [...] these questions coalesce most persistently around the nature of the soul and its relation to the body"; see her monograph John Donne, Body and Soul (Chicago and London: University of Chicago Press, 2008), 5.

36 See, for instance, Marshall, Beliefs and the Dead (see note 3), particularly 6-187.

37 For our purposes, it suffices to simplify what was considered a "good" and a "bad" death. For details, see Houlbrooke, Death, Religion, and the Family (see note 3), 154, 183-96.

38 Jacques Le Goff argues that the doctrine of purgatory was responsible for dramatizing the final moments of life: "L'essentiel, le choix de l'Enfer ou du Paradis, puisque le Purgatoire était l'antichambre assurée du Paradis, pouvait encore se jouer à la dernière minute. Les derniers instants étaient ceux de la dernière chance.” See Jacques Le Goff, La Naissance du Purgatoire (Paris: Gallimard, 1981), 484.

39 Philip Benedict, Christ's Churches Purely Reformed: A Social History of Calvinism (New Haven, CT: Yale University Press, 2002), 507. 


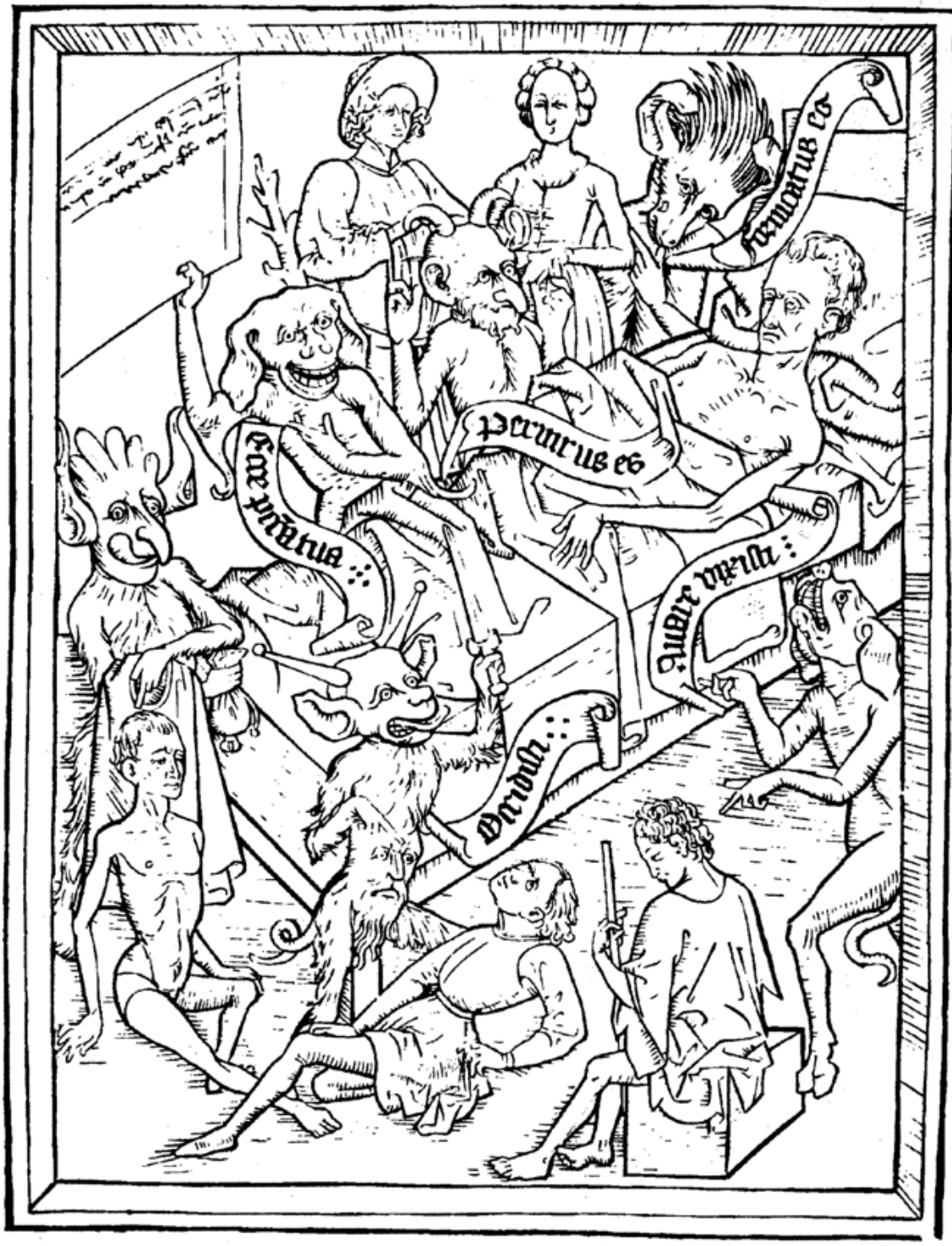

Figure 1: Engraving No. 3 in The Ars Moriendi (Editio Princeps, circa 1450): A Reproduction of the Copy in the British Museum, ed. W. Harry Rylands and George Bullen (London: Wyman \& Sons, 1881).

standers but also teeming with at least an equal horde of snarling devils that confront the dying with his sins ("ecce peccata tua"), particularly echoing his 
avarice ("auare vixisti") and his allegedly extra-marital affairs ("fornicatus es"). ${ }^{40}$ Although Benedict seems to imply vaguely that the diabolical threats disappeared from the Protestant deathbed, a closer look at death manuals of early modern divines such as Thomas Becon or William Perkins suggests the opposite. ${ }^{41}$ Perkins, for instance, writes about "The last combate with the deuill," recounts how the reformer John Knox could "quench the fierie darts," and advises the dying to commend their spirit to the "Lord Iesus" to ensure that "Christ will come vnto thee with all his Angels and be the guider of thy way." 42

It can be said, however, that the Reformation saw a slight shift in emphasis, namely from the death struggle to a general review of the individual's entire life in the last moments and, more importantly in Calvinist circles, to the unresolved question of their election. ${ }^{43}$ Becon in his Salve contends that "the nature and property of God is to wound [...] before he healeth, to throwe downe [...] before he lifteth vp, to kyll [...] before he quickeneth, to condemne [...] before he saueth." 44 At which point in life this happens does not seem to concern Becon, but eventual repentance, brought about by the threat and fear of the devilish hordes around the deathbed, can be read as God's final act of wounding, hurling, killing, and condemning, in other words as his "vertical slingshot" reserved for the elect. Hence, the comportment of a dying person during the final moments was over time considered an indicator of the individual's afterworldly destiny. Dying with equanimity was generally associated with divine election and thus with leaving the world, the flesh, and the devil, a phrase

40 W. Harry Rylands and George Bullen, ed., The Ars Moriendi (Editio Princeps, circa 1450): A Reproduction of the Copy in the British Museum (London: Wyman \& Sons, 1881).

41 Becon, The Sycke Mans Salue (see note 24), 349-50; William Perkins, A Salve for a Sicke Man, or, A Treatise Containing the Nature, Differences, and Kindes of Death as also the Right Manner of Dying Well (Cambridge: John Legate, 1595), 109-11. In Becon, Philemon confirms Epaphroditus's fears that "The manner of Satan, which is the common aduersary of all men, is, when any man is greuously sicke \& like to die, straightways to com vpon him at the beginning very fearcely, \& to shew him selfe terrible vnto him, \& to cast before his eies such a mist [...] that except he taketh hede, he shall see nothing but the fearce wrath [...]" (349). Likewise, Perkins in a postscript of sorts writes about the dangers of "[t]he last combate with the deuill in the pang of death" (109).

42 Perkins, A Salve for a Sicke Man (see note 41), 109-11.

43 Benedict, Christ's Churches Purely Reformed (see note 39), 507.

44 Becon, The Sycke Mans Salue (see note 24), 379; Richard Wunderli and Gerald Broce, "The Final Moment before Death in Early Modern England," The Sixteenth Century Journal 20.2 (1989): 259-75; here 265. 
that surfaces again and again in the ars moriendi before and after its canonization in the Litany of The Book of Common Prayer. ${ }^{45}$

This aspect of leave-taking is conspicuously invoked in the final line of Donne's sonnet, but even on a more subtle level it can be argued that the idea of the deathbed surrounded by a fiendish horde of devils that ought to be defeated is not foreign to Donne either. In his Second Anniversarie, in which the speaker also addresses his own soul's passage to the next world, Donne is clearly aware of the diabolical threat at the point of death:
Thinke Satans Sergeants round about thee bee,
And thinke that but for Legacies they thrust;
Give one thy Pride, to'another give thy Lust:
Give them those sinnes which they gave thee before,
An trust th'immaculate blood to wash thy score. ${ }^{46}$

Here, we can almost see what that one medieval ars manual from around 1450 depicts literally: a number of Satan's delegates sent to seize the speaker's soul. Significantly, however, instead of succumbing to the demonic temptations, the soul is advised to surrender all her earthly burdens to "Satans Sergeants" to be purified by Christ's immaculate blood. If we consider now lines 12-13 of Donne's sonnet again, "So, fall my sinnes, that all may have their right, / To where they'are bred, \& would presse me, to hell," we encounter a similar or related process: everything tainted by earthly sin is cast to hell, and although the

\footnotetext{
45 The triad of leaving the flesh, the world, and the devil does not only feature in the Litany of The Book of Common Prayers of 1549, 1559, and 1662, but it is also a recurring phrase among pre- and post-Reformation ars writers. Erasmus, for instance, refers to death as "the laste fyghte with the enemye" invoking the idea of the miles Christianus seeking the "vyctorye of [over] the flesh, of [over] the worlde, and of [over] the dyuell." Also, Becon writes that "In this world therefore, wherein our life is nothing but a knighthod or warfar, must we lawfully, valeantly \& mightely fight \& striue against our ennemies the deuill, the world \& the flesh, and by seruent and diligent prayer vnto God so triumphe ouer them thorow the help of our graund captain Christ, that we may haue a glorious spoill of our ennemies, \& garnishe our selues with al kind of victorious \& roial robes I meane, all good workes \& godly vertues." See Erasmus, Preparation to Deathe, A2r, A7r; Becon, The Sycke Mans Salue, *6v; Brian Cummings, ed., The Book of Common Prayer: The Texts of 1549, 1559, and 1662 (Oxford: Oxford University Press, 2011), 41, 117, 260. The origin of this triad is hard to determine, but can be traced through its early Christian form all the way back to Plato's The Republic; see Patrick Cullen, Infernal Triad: The Flesh, the World, and the Devil in Spenser and Milton (Princeton, NJ: Princeton University Press, 1974), xxv-xxvi.

46 John Donne, The Second Anniversarie of the Progres of the Soule; Wherein: by Occasion of the Religious Death of Mistris Elizabeth Drury, the Incommodities of the Soule in this Life and her Exaltation in the Next, are Contemplated, 1612, in The Epithalamions, Anniversaries, and Epicedes, ed. Wesley Milgate (Oxford, London, et al.: Clarendon Press, 1978), 39-56, here 1l. 102-06.
} 
hell-ward haulers remain passively obscure, in light of the passage from The Second Anniversarie, "Satans Sergeants" are at least likely candidates for this undertaking. Furthermore, Targoff has observed that " $[\mathrm{t}]$ he gesture of dividing himself into three parts rather than two-body, soul, and sin-reflects Donne's desire to isolate that part of the self that he expects will not fare well at the Last Judgment." ${ }^{47}$ Thus, since sin has been taken care of, the two constituents that are left-body and soul-can be identified as righteous and are therefore eligible for a post-mortem reunion, a commonplace in Donne's thought as we shall see. ${ }^{48}$

This divine imputation leads to the constitution of a new "I," a new union of body and soul, to be acquired on the last pilgrimage. It has been advanced that the "I" in line 6 refers to the body and the soul; much more plausible, as I have already pointed out above, is a reading in which this "I" can "sleepe a space" as a physical body while the ethereal soul, the "ever-waking" part, is contrasted in the following line as a participant in the visio Dei. In the couplet then, the final "I," which follows swiftly after righteousness could have been imputed to the speaker, becomes significantly more relevant: it is here, I argue, that the union of body and soul is restored in heavenly terms and that this "I" assumes a new after-worldly meaning as the metaphor of the pilgrimage comes successfully to a close.

What is so far just a conjectural implication can actually be corroborated by turning to one of Donne's later sermons. In 1620, Donne preached at Lincoln's Inn on Job 19:26, “And thogh after my skin wormes destroy this bodie, yet shal I se God in my flesh.” Throughout his entire sermon, Donne belabors the doctrine of the resurrection including more worldly matters such as putrefaction that may possibly challenge the said doctrine. He uses this verse from Job 19:26 to argue that while all belong to the "Massa damnata" and will see God on the Day of Judgment, not all shall rise to glory. Donne reasons that, whereas some will remain in the old flesh, others will rise in a new flesh to see God, just as Job envisioned it for himself. Together with the verse that follows, "Whome I my self shal se" or in its Vulgate rendering "quem visurus sum ego ipse" (v. 27, my emphases), he concludes that since his flesh is new and devoid of sin, his new heavenly "I" will be constituted of a body and soul again:

47 Targoff, John Donne, Body and Soul (see note 35), 125.

48 The Oxford English Dictionary defines imputation as "[t]he attributing to believers of the righteousness of Christ, and to Christ of human sin, by vicarious substitution" and includes references from near contemporaries of Donne. My analysis relies on the assumption that Donne conceived of the concept similarly. 
Ego, I, I the same body, and the same soul, shall be recompact again, and be identically, numerically, individually the same man; The same integrity of body, and soul, and the same integrity in the Organs of my body, and in the faculties of my soul too; I shall be all there, my body, and my soul, and all my body, and all my soul. ${ }^{49}$

That the soul, which "was put to the slavery to serve that [earthly] body [...] hath once got loose by death," and "in sight and fruition of that God [...] was in no danger," should now "willingly, nay desirously, ambitiously seek this [...] body [...] is the most inconsiderable of consideration," Donne admits. ${ }^{50}$ But he repeats again and again that, according to the passage from Job (and the way he quotes it and lays it out, I would say!), ${ }^{51}$ there is no other possibility for body and soul but that both "receive the crown of glory which shall not fade." ${ }^{25}$ That this idea of a post-mortem union of body and soul is quite dominant in Donne's thought has been shown by Targoff, but it also bears emphasis that such a union runs contrary to the orthodox doctrine of the Church of England that "the soul should feel nothing but liberation at the moment of leaving the body." ${ }^{33}$ For Donne, however, it is beyond doubt that, upon the conclusion of his earthly pilgrimage, his body and soul live together in eternal and untainted integrity.

In spite of its unorthodox charge, I think that this Donnean idiosyncrasy sheds quite some new light on his "This is my playes last scene." As time is running out and as the "last mile" is reduced to the "last inch," the speaker envisions how his earthly self will eventually assume heavenly integrity. His earthly body being subject to putrefaction in its grave and his sins cast to hell, the speaker "only" has to turn to God himself, to "that face" that he feared, and to ask for divine imputation. What has troubled Strier, namely that the purgation of evil is redundant if divine imputation has been granted, can only be understood in the context of Donne's understanding of body and soul: if both body and soul are to experience an eschatological reunion and to assume heavenly integrity, there does not seem to be another way to shear the body of its corruption than a process of spiritual purification of which both imputation and purgation are a part.

49 John Donne, "Sermon No. 3: Preached at Lincolns Inne," 1620, in The Sermons of John Donne, ed. George R. Potter and Evelyn M. Simpson, 10 vols. (Berkeley and Los Angeles, CA: University of California Press, 1957), vol. 3:109-10.

50 Donne, "Sermon No. 3: Preached at Lincolns Inne” (see note 49), 3:109.

51 Only just recently, Alison Knight has raised the issues of Donne's (and others') practices of misquoting Scripture when preaching on this passage. See Alison Knight, "The 'Very, Very Words': (Mis)quoting Scripture in Lancelot Andrewes's and John Donne's Sermons on Job 19:23 - 27," Studies in Philology 111.3 (2014): $442-69$.

52 Donne, “Sermon No. 3: Preached at Lincolns Inne” (see note 49), 3:110.

53 Targoff, John Donne, Body and Soul (see note 35), 79-80. 
The result of this imputative and purgative process is subtly alluded to as a new heavenly self, as a new "I," in the final line of the poem: "For thus $I$ leave the world, the flesh, the devil" (1. 14, my emphasis). This new "I" is entitled to take leave of the world. Or put differently, it is on his last mile, on its last inch presumably, that the speaker of this poem envisions and hopes for a process of purgation and imputation, and it is only through this very process on the metaphorical last pilgrimage that the "I" can assume a new heavenly meaning in that it subsumes the union of both a purified soul and a body, "purg'd" of all things evil.

As was shown in the above, fourteen lines about a last pilgrimage can give rise to some contentious issues; quite a number of them can, however, be explained by further enquiring into the depths of the last pilgrimage as a trope as well as into devotional literature such as the ars moriendi or Donne's sermon, the latter of which illuminating the full potential of the pilgrimage metaphor here. In the poem, the last pilgrimage that the speaker at the point of death has to take is essentially about the in-mortem separation of sin, body, and soul as well as a post-mortem reunion of the latter two into a new heavenly "I": a new set of meaning is instilled into the first personal pronoun once the earthly peregrinations are concluded.

\section{The Pilgrimage Metaphor in Sir Walter Raleigh's Poetry}

In "The Passionate mans Pilgrimage," a poem that has often been attributed to Sir Walter Raleigh, some aspects may be similar to Donne's, but others are indeed markedly different. It begins with a request uttered by the "one at the point of death":

Give me my Scallop shell of quiet, My staffe of Faith to walke upon, My scrip of Joy, Immortal diet, My bottle of salvation:

My Gowne of Glory, hopes true gage,

And thus Ile take my pilgrimage. (ll. 1-6) ${ }^{54}$

54 Throughout this paper, I quote from Sir Walter Raleigh, "The Passionate mans Pilgrimage, supposed to be written by one at the point of death," 1604, in The Poems of Sir Walter Ralegh: A Historical Edition, ed. Michael Rudick. Medieval and Renaissance Texts and Studies, 209 (Tempe, AZ: Arizona Center for Medieval and Renaissance Studies, 1999), 126-27. 
Equipped with the traditional paraphernalia of the medieval place-pilgrim, he "Travels to the land of heauen, / Over the silver mountaines, / Where spring the Nectar fountaines" (11. 10-12). On his "happie blisfull way" (1. 19), he encounters other pilgrims "That have shooke off their gownes of clay, / And goe appareld fresh like mee" (1l. 20-21). The pilgrims are soon "fild with immortalitie" and their heavenly abode is presented fairly ostentatiously and is reminiscent of the final passages of the Book of Revelation, for "the holy paths" are

Strewde with Rubies thicke as gravell

Seelings of Diamonds, Saphire floores,

High walles of Corall and Pearle Bowre. (1l. 30 -34)

The tone, however, shifts and becomes less ornate, for the two stanzas that follow juxtapose the practice of earthly and heavenly justice: in the "Bribeles [bribe-less] hall" of heaven

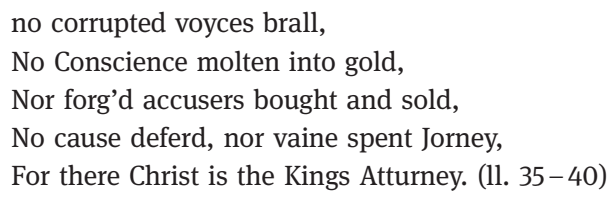

Thus, heaven becomes a place of eternal justice through the atonement of Christ, the "Unblotted Lawyer, true proceeder" (1. 48). The last stanza, then, is fairly tongue-in-cheek (1l. 53-55), but it includes a serious concern of the pilgrim, namely, that his soul live in eternity (1. 56):

And this is my eternall plea,

To him that made Heaven, Earth and Sea,

Seeing my flesh must die so soone,

And want a head to dine next noone,

Just at the stroke when my vaines start and spred

Set on my soule an everlasting head. (11. 51-56)

Here, the "flesh must die" (1. 53), and the convict loses his head, but his soul is provided with an "everlasting head" (1. 56), an uncorrupted version of his body, which will allow him "like a palmer fit, / To tread those blest paths which before I writ” (1l. 57-58). 
To date, there is still no watertight evidence that this poem was written by Raleigh. However, a lot speaks in favor of his authorship. ${ }^{55}$ The poem was first published in 1604, appended probably as a "printer's filler" to a collection of love poetry entitled Daiphantus, or, The Passions of Love (by Anthony Scoloker), but was not printed again until twenty years later. If Raleigh is indeed the author, the date of composition would most likely be between November 17 and December 6, 1603, when he had been convicted, was incarcerated in the Tower, and faced a traitor's death (for the first time). ${ }^{56}$ Pierre Lefranc and Philip Edwards cast doubt on Raleigh's authorship of the poem due to its disappearance from print until three years after his actual death in 1618, its blatantly Catholic imagery, ${ }^{57}$ and various other aspects that they deem uncharacteristic of his poetry. ${ }^{58}$

Others such as Stephen Greenblatt and Rosemund Tuve consider Raleigh a more than valid candidate for being the author of the poem. While the former estheticizes Raleigh's choice of imagery arguing that his "poems fully realize and elaborate roles which are, of necessity, only partially acted out in life," the latter adduces evidence for Raleigh's ownership of a mid-fifteenth-century book of hours (MS Bodleian Add. A. 185) that exhibits an "illumination picturing St. James [...] with the scallop-shell, staff, scrip, gown of Ralegh's poem." 59 This, his earlier use of pilgrimage imagery in a poem that starts with "As you came from the holy land / of Walsinghame-" and some other instances in Raleigh's prose suggest his familiarity with the pilgrimage trope, Greenblatt maintains; furthermore, he argues that ostentatious after-worldly imagery need not be indicative of Catholicism as both Milton and Bunyan make use of it in their writings as

55 For an exhaustive overview on the debate of authorship, see Michael Rudick, "Attributions, Arrangement, Chronology,” The Poems of Sir Walter Ralegh (see note 54), lxx, n. 75.

56 Rudick, "Attributions, Arrangement, Chronology” (see note 54), lxix-lxx; Agnes M. C. Latham, "Notes," The Poems of Sir Walter Ralegh, ed. Agnes M. C. Latham (London: Routledge, 1951), $141-42$.

57 In The Faerie Queene, for instance, Spenser uses "a Iacobs staffe” to identify the mischivous Archimago's “old faith,” see Edmund Spenser, The Faerie Queene, 1590 / 1596, ed. Albert Charles Hamilton, Hiroshi Yamashita, Toshiyuki Suzuku (Harlow: Pearson, 2007), bk. 1, cant. 6, stan. 35.

58 Pierre Lefranc, Sir Walter Ralegh, Écrivain: l'œvre et les idées (Paris: Colin, 1968), 84-85; Philip Edwards, Sir Walter Ralegh (London: Longmans, Green and Co., 1953), 93-96.

59 Stephen Greenblatt, Sir Walter Ralegh: The Renaissance Man and His Roles (New Haven, CT, and London: Yale University Press, 1973), 123; Rosemond Tuve, Elizabethan and Metaphysical Imagery: Renaissance Poetic and Twentieth-Century Critics (1947; Chicago: University of Chicago Press, 1968), 308, n. 29; also see Rosemond Tuve, "Spenser and Some Pictorial Conventions, with Particular Reference to Illuminated Manuscripts,” Studies in Philology 37.2 (1940): 14976; here 151, n. 3. 
well. ${ }^{60}$ To me, Greenblatt's and Tuve's arguments outweigh the ones of Lefranc and Edwards, not least because the latter are not able to present a valid alternative to Raleigh. It is because of this reason that I base the following on the assumption that Raleigh is indeed the author of "The Passionate mans Pilgrimage."

In terms of figurative language, the poem offers quite a number of instances of which only some can be considered in depth here. In the first stanza, words like "Scallop shell," "staffe," "bottle," and "Gowne” are redolent of the pre-Reformation place-pilgrimage, but they are invariably used as quantifiers, semantic receptacles, so to speak, that contain components of the Christian faith that are not foreign to Protestantism at all (see my emphases): "Scallop shell of quiet," "staff of Faith," "Scrip of Joy," "bottle of salvation," "Gown of Glory." Here, one could even argue that a sense of quietness, steadfastness in faith, the prospect of joy, the probability of salvation, and the expectation of celestial glory are indispensable constituents of a "good death" according to the ars moriendi literature mentioned above. On a further level, these constituents are cast into metaphors that not only borrow medieval pilgrimage imagery but they also artfully anticipate the fact that this journey will be the pilgrim's last.

The finality of the pilgrim's journey is confirmed in the next stanza, which is replete with metaphorical references to fluids. "Blood" will be his body's "balmer," a rare word in this sense for which the Oxford English Dictionary references only this line from Raleigh's poem. The line can be read in two ways: either Blood is personified as a "balmer," a person who embalms, or blood is the fluid in which the victim is embalmed. One way or the other, it already suggests the violent scene on the scaffold: perhaps the poet deliberately does not specify whether the execution will be carried out exclusively by decapitation, as the final stanza might suggest, or by hanging, drawing, and quartering which also includes decollation and which would have been the common fate of traitors to which Raleigh had been sentenced by Lord Popham originally. ${ }^{61}$ In any event, upon leaving the bloodbath on the scaffold, he (his soul) is seen to travel "like a white Palmer" to heaven (11. 9-10), where he kisses the "Bowle of bliss" and drinks some eternal substance "On every milken hill” (ll. 13-16). Abandoning the earthly body in its pool of blood, here, is sharply contrasted with ethereal whiteness, implied on the one hand in the purity of the pilgrim's

60 Greenblatt, Sir Walter Ralegh (see note 59), $123-24$.

61 Mark Nicholls and Penry Williams, Sir Walter Raleigh: In Life and Legend (London and New York: Continuum, 2011), 213; John H. Baker, "Criminal Courts and Procedure at Common Law, 1550-1800," Crime in England, 1550-1800, ed. James S. Cockburn (London: Methuen, 1977), 42. 
soul and on the other hand in the subtle allusion to the land of milk and honey. Importantly, in these lines, the soul is not just leaving the body but the metaphor of the pilgrim quenching the soul's thirst by drinking from the "Bowle of bliss" also suggests a process of after-worldly rejuvenation, a process in which "more peacefull Pilgrims" will participate in the next stanza.

For every metaphorical instance that has so far been mentioned it can be said that it purports to approximate something inexpressible in human terms. Ideas like heavenly quietness, unwavering faith, celestial joy and bliss, eternal salvation and glory (and perhaps even the violence with regards to the convict's end) are hard to conceive of literally. But what we witness in this poem is exactly what has been advanced by Weder following Ricœur, namely that a new set of semantics is generated through a religious metaphor by combining a "transcendent subject" with an "immanent predicate" (see above): for example, a staff of faith, I would argue, becomes much more meaningful to the pilgrim-convict as it bespeaks a supportive, this-worldly device rather than "just" faith alone. Likewise, salvation and bliss can perhaps be better conceived of if they can be imbibed. Hence, all the metaphors thus used aim at bridging the divide between this world and the one to come.

Through the combination of this-worldly terms with after-worldly concerns, the latter are not only rendered more accessible to the "one at the point of death," but both constitute the broader, metaphorical stage of the last pilgrimage and thereby offer a new set of "heavenly semantics," so to speak. As the metaphorical pilgrimage leads him to "heavens Bribeles hall," the pilgrim is presented with what seem to be never-experienced legal conditions: from the pilgrimconvict's perspective, there is no more corruption ("no corrupted voyces brall," 1. 36), clear conscience is a matter of course ("No Conscience molten into gold," 1. 37), ${ }^{62}$ prosecutors are not "bought and sold" (1. 38), nor is he any longer subject to legal inertia by being sent from court to court ("No cause deferd, nor vaine spent Jorney," 1. 39). Even the royal authority is deposed, for "Christ is the Kings Atturney” (1. 40). All this fits very nicely into a picture of a Raleigh who relentlessly inveighed against the charges put forward by his prosecutors: to this testify the many extant letters to his wife Bess and to others as well as court records, in which he is said to protest against being tried "by no law but by the Spanish inquisition." ${ }^{63}$ Thus, the heavenly tribunal presided over by a

62 Incidentally, Raleigh had previously appealed to his accusers' "reputatione of conscience," though to no avail; see Sir Walter Raleigh, The Letters of Sir Walter Ralegh, ed. Agnes M. C. Latham and Joyce Youings (Exeter: University of Exeter Press, 1999), 252.

63 Raleigh, The Letters of Sir Walter Ralegh (see note 62), 247-67. "And I will tell you, Master Atturney, if you condemne me upon bare inferences, and will not bring my accuser to my face: 
taintless Christ figures as an unprecedented scene of justice on the convict's and/or Raleigh's last pilgrimage.

These strong contrasts between the present world, for which he expresses such contempt, and the one to come are negotiated by the overall conceit of the last pilgrimage. In this regard, Greenblatt argues that "[t]he role of pilgrim resolved the conflicting visions within him [Raleigh], the Golden World and the world of death." ${ }^{64}$ And in fact, it is through this metaphor that the pilgrim begins to associate himself with a new world that lies beyond earthly and, in particular, beyond courtly corruption. Though he has not departed yet, the poem sets the stage to do so as soon as the way to a new heavenly reality has been paved along the pilgrimage that lies ahead. In this confident mood, the pilgrim is not only able to denounce earthly authorities, but he is also capable of engaging in gallows humor ("Seeing my flesh must die so soone, / And want a head to dine next noone," 11. 53-4). His final plea that his decollated self be reconstituted with "an everlasting head" (1. 56) to be placed on his soul, on the one hand, is suggestive of a long-standing tradition in which "[s]alvation and eternal life are inconceivable, even impossible without heads and skulls." 65 On the other hand, the prospect of his newly equipped soul invites the equanimity of the two final lines in which he expresses his readiness to leave this world.

\section{Conclusion}

The attempt of the investigation above was to inquire into two rather different poems that make use of the last pilgrimage as a Christian metaphor to express the passage from this life to the next. The literary tradition of the ars moriendi was read as paving the way for this metaphor to open up new perspectives of the afterlife in the two poems discussed. While the metaphorical potential of Donne's poem reveals a semantic innovation in the constitution of a new heavenly "I" in which both the purified body and soul coalesce, Raleigh's pilgrim foresees a new set of celestial semantics as he faces the heavenly court of untainted justice. Although Raleigh uses the imagery of the medieval place pilgrim-

you may try me by no law but by the Spanish inquisition;" see Sir Thomas Overbury, The Arraignment and Conviction of Sr Walter Rawleigh at the Kings Bench-barre at Winchester (London: William Wilson, 1648), 18.

64 Greenblatt, Sir Walter Ralegh (see note 59), 124.

65 Catrien Santing and Barbara Baert, "Introduction," Disembodied Heads in Medieval and Early Modern Culture, ed. Catrien Santing, Barbara Baert, and Anita Traninger. Intersections: Interdisciplinary Studies in Early Modern Culture, 28 (Leiden: Brill, 2013), 9. 
age, his express use of metaphors throughout the poem clearly points to the pervasive trope of the life pilgrimage that comes to a close rather than to a placebound journey to a shrine on earth. Both poets obviously engage with the oldnew metaphor of life as a pilgrimage. For both it provides the figurative framework for the dying to take leave of the world, but the metaphor in each case unfolds two very different heavenly scenarios. 